\title{
Tryptase Beta-2
}

National Cancer Institute

\section{Source}

National Cancer Institute. Tryptase Beta-2. NCI Thesaurus. Code C124248.

Tryptase beta-2 (275 aa, $\sim 31 \mathrm{kDa}$ ) is encoded by the human TPSB2 gene. This protein is involved in protein degradation. 